Article

\title{
Crop Characteristics of Aquatic Macrophytes for Use as a Substrate in Anaerobic Digestion Plants-A Study from Germany
}

\author{
Lucie Moeller ${ }^{1}$, Aline Bauer ${ }^{1}$, Harald Wedwitschka ${ }^{2}$, Walter Stinner ${ }^{2}$ and Andreas Zehnsdorf ${ }^{1, *}$ \\ 1 Centre for Environmental Biotechnology, UFZ-Helmholtz Centre for Environmental Research, \\ Permoserstraße 15, 04318 Leipzig, Germany; lucie.moeller@ufz.de (L.M.); aline.bauer@ufz.de (A.B.) \\ 2 German Biomass Research Centre-DBFZ, Torgauer Straße 116, 04347 Leipzig, Germany; \\ harald.wedwitschka@dbfz.de (H.W.); walter.stinner@dbfz.de (W.S.) \\ * Correspondence: andreas.zehnsdorf@ufz.de; Tel.: +49-341-235-1850
}

Received: 19 September 2018; Accepted: 29 October 2018; Published: 2 November 2018

\begin{abstract}
Several thousand metric tonnes of aquatic biomass are removed from water bodies every year, so that these waters can continue to be used for ship and boat traffic and for leisure activities. The mowed material is generally disposed off without any further use. Therefore, the crop properties of samples from 39 weed control measures all over Germany were examined to assess the suitability of aquatic plant biomass as a substrate for anaerobic digestion systems. Analysis of the crop samples consisted of the identification of plant species and the evaluation of sediment contents and concentrations of macroelements. The methane yield was determined for selected aquatic plants. Analysis revealed a carbon/nitrogen ratio $(\mathrm{C} / \mathrm{N})$ of between 10 and 20 in $74 \%$ of samples. The concentrations of nitrogen and phosphorous in the samples were comparable to grass silages. With regard to heavy metal concentrations, the threshold values for biowaste for nickel, zinc, and cadmium were exceeded in three samples. There were no significant seasonal differences in substrate characteristics and qualities. The specific methane yields of individual aquatic plants were between 142 and $372 \mathrm{~L}_{\mathrm{CH} 4} / \mathrm{kg}$ volatile solids (VS). The results of this study showed that aquatic macrophytes can be used as substrates in anaerobic digestion plants without any restrictions.
\end{abstract}

Keywords: aquatic macrophytes; substrate; anaerobic digestion; crop characteristics; biogas; methane; aquatic biomass

\section{Introduction}

Aquatic plants are valuable components of aquatic ecosystems. They produce oxygen and perform a water-purification function-for example by binding heavy metals [1] and removing nutrient loads [2-4]. Moreover, aquatic macrophytes can also serve as a hiding place and location for binding for aquatic fauna and its offspring. Nonetheless, it can occur that aquatic plants form plant mats in water as a result of overgrowth; these plant mats can impair the use of bodies of water for humans. This can have serious economic consequences for the operators of these bodies of water. Aquatic plants hinder the passage of ships and boats and impact negatively on the usefulness of bodies of water for leisure purposes (bathing, fishing and other sporting activities). Dead plant remnants can also accumulate at narrow points in bodies of water and hinder the flow of water, which can lead to the backing-up of water or even to flooding. For hydroelectric power plants, such accumulations of aquatic plants in front of turbine inlets represent a serious challenge and can result in significant reductions in output. 
In addition to the consequences described above, invasive neophytes (very competitive, non-resident plants with high expansion capacity) can also have a negative influence on competing domestic flora, which may even be completely displaced in extreme cases; this leads to a reduction in the domestic population and its biodiversity [5]. The neophytes that are involved in this regard in bodies of fresh water in Germany include: Water fern (Azolla filiculoides LAM.), water pennywort (Hydrocotyle ranunculoides L. F.), swamp stonecrop (Crassula helmsii (Kirk) COCKAYNE, waterweed (Egeria densa PLANCH., Elodea canadensis MiCHX., and Elodea nuttallii (PLANCH.) H. ST. JOHN), variable-leaf watermilfoil (Myriophyllum heterophyllum MicHX.), straight vallisneria (Vallisneria spiralis L.) and duckweed (Lemna sp.) [6]. strongly affected by Elodea are the reservoir lakes along the Ruhr river in North Rhine-Westphalia, which were completely blocked and overgrown in certain cases, due to their low water levels $[7,8]$.

A comprehensive overview of neophytes and the corresponding management and control strategies has recently been put together by Hussner et al. [9]. There is no single combating measure that is applicable for all invasive neophytes in all types of bodies of water [10]. The use of herbicides is forbidden in Germany for controlling overgrowth of aquatic plants, and thus the removal of aquatic plants by cutting using various items of equipment has become established [11]. The measure results in considerable cost factors for the operators of bodies of water. The cost of controlling individual species of invasive aquatic plants in Europe amounts to several million euros per annum [10]. Herbes et al. (2018) [12] estimated total cost of $€ 31.68$ per tonne of fresh mass for an overgrown lake that contains mainly Elodea nuttallii. The authors presumed the use of one small weed-cutting boat with front-mounted machinery (Berky 6410) that alternates between using the cutting and collecting tools.

The harvested aquatic biomass is generally disposed of without being put to any further use. Sometimes it is even left to rot on the shores of the lake, which helps to foster the growth of aquatic plants the following year, due to the supply of nutrients from the rotten biomass. As an alternative, the harvested aquatic plants could be used as a substrate for biogas plants. Initial investigations have shown that the potential of aquatic plants for biogas production should not be underestimated. For example, samples of Western waterweed (E. nuttallii) from five different lakes in Germany had yields of 415-520 $\mathrm{L}_{\text {biogas }} / \mathrm{kg}$ volatile solids (VS) [8]. A study by Lizasoain et al. [13] described the possibility of using Phragmites australis for anaerobic fermentation. After pretreatment by means of steam explosion was carried out, biogas yields of up to $677 \mathrm{~L}_{\text {biogas }} / \mathrm{kg}$ VS were achieved. Two recent studies from India have demonstrated the anaerobic degradability of duckweed (Lemna sp.) [14,15]. Yadav et al. [14] tested the co-digestion of diluted shredded duckweed (Lemna sp.) with cattle dung in various ratios. In this study, the highest cumulative biogas production of $12 \mathrm{~L}$ was achieved by using a ratio of 1:1 $(v / v)$ of duckweed slurry to cattle dung, which showed good potential for the use of duckweed as a co-substrate in anaerobic digestion (AD). Gaur et al. [15] investigated the effect of thermal pre-treatment of duckweed (Lemna gibba) on the specific methane yield (SMY). The authors found that it is possible to achieve an SMY that is up to 24 times higher by autoclaving duckweed at $120{ }^{\circ} \mathrm{C}(1 \mathrm{bar})$ for $30 \mathrm{~min}$.

Aquatic plants offer certain advantages, such as no necessity for fertilizers, and no use of agricultural land, when compared to plants conventionally used for energy production, such as maize, sugar beet and grain. In addition, aquatic plants do not compete with agriculturally produced foodstuffs for humans or animal feeds in terms of land use.

Alongside biogas yields, other factors are also of importance in the use of aquatic plants for energy production. One disadvantage that is commonly ascribed to aquatic plants is the entry into biogas fermenters of the sediment that is attached to the aquatic plants, which contributes to a reduction of the active fermenter volume in the long term. Another supposed disadvantage is the high water content of many aquatic plants, which leads to dilution of the digestate and also contributes to the low biogas yield of the fresh mass. On the other hand, aquatic plants provide nutrients and trace elements and can thus be beneficial for the substrate composition $[8,16]$. For example, it is known that waterweed stores phosphorus in its tissue that it takes both from the water and the sediment [3]. 
For this reason, the suitability of the harvested aquatic plant material as a biogas substrate was tested in greater detail. Over two harvesting periods (autumn 2015 and summer 2016), the sediment and nutrient contents of samples of harvested aquatic plants from all over Germany were investigated. The biogas-production potential of selected aquatic plants was determined. The results have provided findings that had been lacking in previous research on management strategies, which generally concentrate on the removal, but not the subsequent re-use of the aquatic biomass.

\section{Materials and Methods}

\subsection{Origin of Aquatic Plant Material}

In 2015/2016, a nationwide inquiry of the responsible water authorities, river managers and users, as well as operators of mowing boats, was carried out. Thereby, it was determined how much biomass was harvested during the weed controls of flowing and still waters. A total of 1123 questionnaires were sent out, of which 408 responses were received. This corresponds to a return rate of $36.3 \%$. On the basis of this data, weeding was determined from 140 bodies of flowing water and 90 bodies of standing water. This corresponds to a ratio of 1.6:1. Taking this into account, 20 bodies of flowing water and 10 bodies of standing water were selected for the further examination of the aquatic plant biomass (at least 10\% per water body type). In addition, samples from the summer mowing and the autumn mowing were examined in order to identify any seasonal differences.

Samples of mowed material were collected by water maintenance staff during mowing measures and sent in buckets by post to the Helmholtz Centre for Environmental Research-UFZ. The sample weight was mostly between 1 and $6 \mathrm{~kg}$. Some bodies of water were sampled multiple times.

The first sampling period was in autumn 2015 and lasted two months (September to October 2015). 26 samples were taken during this time; seven samples originated from standing bodies of water (three lakes, two ponds and one dam) and 19 samples came from 15 flowing bodies of water.

The second sampling period was during summer 2016 (June to August 2016). The total of 13 samples consisted of seven samples from flowing bodies of water and six samples from five standing bodies of water (two ponds, two lakes and one lido).

The harvesting of aquatic plants was performed using mowing boats and various items of auxiliary equipment such a mowing basket, weed rake, slope mower, knife mower and drag scythe.

\subsection{Sample Treatment and Analyses}

The contents of the buckets were washed in order to quantify the content of sediments and impurities after arrival at the UFZ. The separated sediment was weighed and dried for the determination of its total solid content (TS) according to the standard of the german institute for standardization DIN 12880. Samples of the aquatic plants were taken and prepared for herbarium in order to determine the aquatic plant species. The washed material was weighed and further dried at $60{ }^{\circ} \mathrm{C}$ for the determination of TS. The dried material was used for the determination of volatile solids (VS) according to DIN 12879 and for the analysis of carbon and nitrogen contents using a TruSpec elemental analyzer (Leco, St Joseph, MI, USA). The elements aluminum, boron, calcium, iron, potassium, magnesium, manganese, phosphorous, sulfur and zinc in the plant samples were measured using the ICP-OES (ARCOS, SPECTRO Analytical Instruments GmbH, Kleve, Germany) according to the US-EPA method 200.7. The elements arsenic, cadmium, cobalt, chrome, copper, molybdenum, nickel and lead were measured with the ICP-MS (ICAPQs, Thermo Fisher Scientific GmbH, Bremen, Germany) according to the US-EPA method 200.8, due to their lower limit of detection.

\subsection{Biochemical Methane Potential Test}

The methane yield from selected aquatic plants was determined according to the German guideline for the fermentation of organic materials VDI 4630. Aquatic plants from mowing measures (sample nos. 3, 7, 12, 20, 21 and 37; TS and VS see Tables 1 and 2) were chopped into $4 \mathrm{~mm}$ pieces and 
stored at $-18{ }^{\circ} \mathrm{C}$ until they were used to determine their methane potential. In addition, fresh samples of four aquatic plants (E. nuttallii (TS $=6.42 \%$ fresh mass $(\mathrm{FM})$; VS $=79.65 \% \mathrm{TS}$ ), M. heterophyllum (TS $=5.71 \%$ FM; VS $=73.92 \% \mathrm{TS}$ ), Ranunculus fluitans (TS $=6.42 \% \mathrm{FM}$; VS $=82.21 \% \mathrm{TS}$ ) and Callitriche sp. (TS $=6.52 \% \mathrm{FM}$; VS $=61.88 \% \mathrm{TS}$ ) ) were harvested from flowing bodies of water in Leipzig (the Parthe river and Karl-Heine-Kanal), chopped in a cutting mill (SM2000, Retsch, Haan, Germany) with a milling coarseness of $4 \mathrm{~mm}$ and used for the determination of their methane potential without any storage phase.

In the case of aquatic plant sample nos. 3, 12, 20, 21 and 37, the Automatic Methane Potential Test System (AMPTS, Company Bioprocesscontrol, Lund, Schweden) of the German Biomass Research Centre (DBFZ) was used for the determination of biochemical methane potential (BMP). The samples consisted of $400 \mathrm{~g}$ inoculum and app. $2.5 \mathrm{~g}$ volatile solids (VS) of the sample material, each in 3 replications. The pure inoculum was measured to determine its methane yield and to subtract it from the other samples. The inoculum consisted of digestate of the research biogas plant of the Deutsches Biomasseforschungszentrum (DBFZ) which was operated with cattle manure and corn silage as substrate material. The inoculum was sieved and incubated without feeding for three days at room temperature prior its use. The test was terminated after the daily gas production was below $0.5 \%$ of the total gas production for 5 consecutive days. The BMP test was operated under mesophilic conditions $\left(38^{\circ} \mathrm{C}\right)$; microcrystalline cellulose was used as reference substrate. The methane yields were standardized $\left(273.15 \mathrm{~K}, 1.01325 \times 10^{5} \mathrm{~Pa}\right)$.

The methane potential of the remaining sample no. 7 and of aquatic plants harvested from flowing bodies of water in Leipzig was determined in a fermentation batch test system (FBTS) at the Helmholtz Centre for Environmental Research-UFZ as described in Moeller et al. [17]. The digestate used as inoculum originated from the research anaerobic digestion (AD) plant of the DBFZ in all tests. This material was first sieved through a sieve with a mesh size of $5 \mathrm{~mm}$ and then incubated anaerobically for one week at $37^{\circ} \mathrm{C}$ in $5 \mathrm{~L}$ bottles in a tempered incubator for outgassing prior to being used for batch experiments. The digestate had the following characteristics after sieving: TS $=7.2 \pm 0.2 \%$; $\mathrm{VS}=76.4 \pm 0.6 \% \mathrm{TS} ; 221 \pm 36 \mathrm{mg} / \mathrm{L}$ acetate; $19 \pm 3 \mathrm{mg} / \mathrm{L}$ propionate; $<1 \mathrm{mg} / \mathrm{L}$ butyrate.

The 500-mL-test bottles containing $400 \mathrm{~mL}$ of the mixtures of the inoculum and aquatic plants as substrate were incubated at mesophilic temperature $\left(38^{\circ} \mathrm{C}\right)$. Each variant was performed three times in order to ensure statistical reliability. The methane volume was measured continuously in the case of AMPTS systems. In the case of FBTS, the methane percentage in biogas was determined twice a week by gas chromatography with an Agilent GC 6850 WLD wavelength detector (Agilent Technologies, Santa Clara, CA, USA) using an HP Plot separation column and argon as carrier gas. The normalized volume of the methane was calculated according to the VDI 4630 guideline. The fermentation batch tests lasted until the termination criterion (i.e., daily biogas rate equivalent to less than $1 \%$ of the total volume of biogas produced up to that time) was achieved. 
Table 1. Properties of plant material in samples from standing bodies of water (samples 8-13 are from summer harvesting).

\begin{tabular}{|c|c|c|c|c|c|c|}
\hline Sample No. & Federal State & Type of Water Body & Plant Species in the Sample & Sediment Content (\% TS) & $\mathrm{TS}_{\text {Biomass }}(\% \mathrm{FM})$ & $\mathrm{VS}_{\text {Biomass }}(\% \mathrm{TS})$ \\
\hline 1 & $\mathrm{BE}$ & Lake & Water-starwort (Callitriche sp.) & 0.91 & 11.3 & 74.7 \\
\hline 2 & SX & Lake & Watermilfoil (Myriophyllum heterophyllum, M. spicatum) & 2.21 & 6.76 & 81.0 \\
\hline 3 & BW & Lake & Water horsetail (Equisetum fluviatile) & 0.90 & 19.2 & 82.5 \\
\hline 4 & SX & Dam & Spiny water nymph (Najas marina) & 0.44 & 5.00 & 77.6 \\
\hline 5 & BW & Pond & $\begin{array}{l}\text { Broadleaf cattail (Typha latifolia), Lakeshore bulrush } \\
\text { (Schoenoplectus lacustris) }\end{array}$ & 0.86 & 9.20 & 93.9 \\
\hline 6 & BW & Pond & Yellow water-lily (Nuphar lutea) & 3.10 & 14.4 & 80.9 \\
\hline 7 & BW & Pond & Yellow water-lily (Nuphar lutea) & 2.70 & 5.90 & 86.3 \\
\hline 8 & NRW & Lido & Watermilfoil (Myriophyllum sp.) & 13.40 & 19.2 & 47.2 \\
\hline 9 & BA & Lake & Bur-reed (Sparganium erectum) & 0.30 & 7.6 & 71.1 \\
\hline 10 & BA & Lake & Sago pondweed (Potamogeton pectinatus) & 0.80 & 24.5 & 75.8 \\
\hline 11 & BA & Lake & Sago pondweed (Potamogeton pectinatus) & 0.52 & 12.1 & 66.3 \\
\hline 12 & BA & Lake & Western waterweed (Elodea nutallii) & 0.04 & 8.31 & 82.4 \\
\hline 13 & BA & Lake & Floating pondweed (Potamogeton natans) & 0.40 & 11.0 & 53.0 \\
\hline
\end{tabular}

BA—Bavaria, BE—Berlin, BW—Baden-Württemberg, NRW—North Rhine-Westphalia, SX—Saxony. 
Table 2. Properties of plant material in samples from flowing bodies of water (samples 33-39 are from summer harvesting).

\begin{tabular}{|c|c|c|c|c|c|c|}
\hline Sample No. & Federal State & Type of Water Body & Plant Species in the Sample & Sediment Content (\% TS) & $\mathrm{TS}_{\text {Biomass }}(\% \mathrm{FM})$ & $\mathrm{VS}_{\text {Biomass }}(\% \mathrm{TS})$ \\
\hline 14 & NRW & River & Bur-reed (Sparganium sp.) & 0.57 & 11.9 & 84.2 \\
\hline 15 & NRW & River & Bur-reed (Sparganium sp.) & 0.40 & 8.40 & 89.3 \\
\hline 16 & NRW & Ditch & Reed (Phragmites australis), Hornwort (Ceratophyllum sp.) & 0.68 & 5.62 & 90.5 \\
\hline 17 & MWP & Ditch & $\begin{array}{l}\text { Floating sweet-grass (Glyceria fluitans), Duckweed } \\
\text { (Lemna minor) }\end{array}$ & 2.00 & 10.4 & 87.6 \\
\hline 18 & BB & Ditch & Bur-reed (Sparganium sp.) & 0.33 & 19.6 & 84.6 \\
\hline 19 & BB & River & $\begin{array}{l}\text { Reed (Phragmites australis), Floating sweet-grass } \\
\text { (Glyceria fluitans) }\end{array}$ & 0.09 & 10.8 & 87.5 \\
\hline 20 & BB & River & Floating sweet-grass (Glyceria fluitans) & 0.68 & 6.07 & 81.6 \\
\hline 21 & BB & River & Reed (Phragmites australis) & 8.70 & 14.0 & 93.8 \\
\hline 22 & BW & Channel & Bur-reed (Sparganium sp.) & 0.73 & 7.71 & 84.4 \\
\hline 23 & BW & Ditch & Western waterweed (Elodea nutallii) & 0.40 & 5.45 & 88.1 \\
\hline 24 & $\mathrm{HB}$ & Channel & Watermilfoil (Myriophyllum spicatum) & 1.90 & 10.1 & 77.9 \\
\hline 25 & $\mathrm{HB}$ & Ditch & $\begin{array}{l}\text { Canadian waterweed (Elodea canadiensis), Duckweed } \\
\text { (Lemna minor) }\end{array}$ & 2.85 & 9.28 & 78.6 \\
\hline 26 & SX & River & Western waterweed (Elodea nutalii) & 0.18 & 7.40 & 78.5 \\
\hline 27 & LS & Channel & Sedge (Carex sp.), Bur-reed (Sparganium sp.), Iris (Iris sp.) & 3.90 & 13.2 & 88.7 \\
\hline 28 & LS & Channel & $\begin{array}{l}\text { Sedge (Carex sp.), } \\
\text { Waterweed (Elodea nutallii, E. canadensis) }\end{array}$ & 0.17 & 9.30 & 88.9 \\
\hline 29 & BW & Channel & $\begin{array}{l}\text { River water-crowfoot (Ranunculus fluitans), Duckweed } \\
\text { (Lemna minor) }\end{array}$ & 0.94 & 8.20 & 85.8 \\
\hline 30 & BB & River & Reed (Phragmites australis) & 0.22 & 22.0 & 91.6 \\
\hline 31 & MWP & River & River water-crowfoot (Ranunculus fluitans) & 0.40 & 8.45 & 81.0 \\
\hline 32 & SA & River & Bur-reed (Sparganium erectum), Duckweed (Lemna minor) & 1.10 & 7.20 & 73.2 \\
\hline 33 & BB & Channel & $\begin{array}{l}\text { Watermilfoil (Myriophyllum sp.), Duckweed } \\
\text { (Lemna minor), Reed (Phragmites australis) }\end{array}$ & 0.30 & 10.8 & 59.0 \\
\hline 34 & BB & Channel & $\begin{array}{l}\text { Watermilfoil (Myriophyllum sp.), Duckweed } \\
\text { (Lemna minor), Water lily (Nymphaea sp.) }\end{array}$ & 0.60 & 8.1 & 77.7 \\
\hline 35 & LS & Channel & Reed (Phragmites australis), Hedge grasses & 0.80 & 35.8 & 88.5 \\
\hline 36 & BA & River & River water-crowfoot (Ranunculus fluitans) & 0.80 & 5.0 & 61.1 \\
\hline 37 & NRW & River & Bur-reed (Sparganium sp.) & 0.30 & 5.2 & 77.0 \\
\hline 38 & BB & River & $\begin{array}{l}\text { Bur-reed (Sparganium erectum), Duckweed (Lemna minor), } \\
\text { Water lily (Nymphaea) }\end{array}$ & 0.22 & 5.2 & 80.4 \\
\hline 39 & SX & River & Duckweed (Lemna minor), Reed (Phragmites australis) & 0.07 & 6.2 & 81.2 \\
\hline
\end{tabular}

BA-Bavaria, BB-Brandenburg, BW-Baden-Württemberg, HB-Hanseatic City of Bremen, LS-Lower Saxony, MWP—Mecklenburg-Western Pomerania, NRW—North Rhine-Westphalia, SA-Saxony-Anhalt, SX-Saxony. 


\section{Results and Discussion}

\subsection{Aquatic Plant Species}

The properties of the individual harvested samples with regard to plant species and sediment contents are summarized in Table 1 for standing bodies of water and in Table 2 for flowing bodies of water. In total, 18 aquatic plant species were identified in the samples. Interestingly, only one mixed sample (sample no. 5) came from standing bodies of water, whereas the other samples all contained just one species. In the case of the flowing bodies of water, the ratio of mixed samples to single-species samples was one to one.

Bur-reed (Sparganium sp.), which was present in a total of nine samples, was most commonly represented, followed by duckweed (L. minor) in eight samples and reed (P. australis) in seven samples (Figure 1). All these aquatic plants were primarily harvested in flowing bodies of water in both summer and autumn. The only clear trend as regards seasonal dependency was identified in the case of the spiny water nymph (Nymphaea sp.) and the sago pondweed (Potamogeton sp.), as these species were only found in the summer samples.

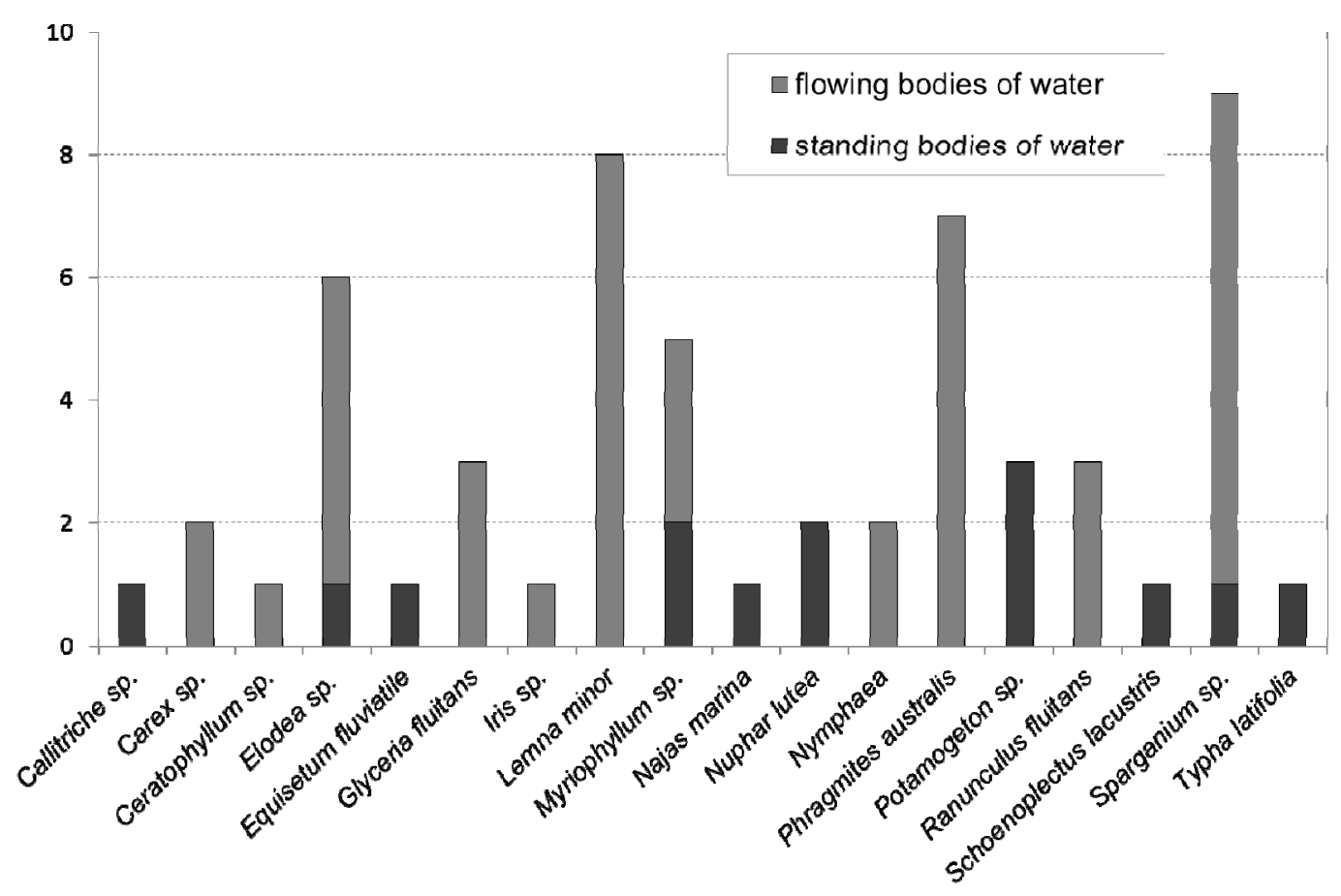

Figure 1. Number of individual plant species in the probes investigated, sorted by type of body of water (standing versus flowing).

Classifying the plant species in terms of their growth forms, ten of them are hydrophytes (aquatic plants that are attached to or rooted in the bottom), seven are helophytes (shore or marsh plants) and one is a pleustophyte (freely floating aquatic plants).

Neophytes were present in 14 of the samples, and a number of neophytes were present together in some samples (see also Tables 1 and 2). Duckweed (L. minor) was identified in eight samples, waterweed species (Elodea sp.) in six samples and variable-leaf watermilfoil (M. heterophyllum) in four samples.

\subsection{Sediments and Extraneous Materials}

As illustrated by the data in Tables 1 and 2, the sediment content of the harvested material was less than $1 \%$ TS in $74 \%$ of the samples, and the sediment content was above $4 \%$ TS in just two cases (samples 8 and 21). The aquatic plant samples from summer harvesting contained significantly less 
sediment than the autumn samples: With one exception, the sediment content of the summer samples was less than $1 \%$ TS. In general, the sediment most frequently contained sludge (in 33 samples), and also sand (in four samples) and gravel (in one sample).

The most frequently occurring extraneous materials were branches and leaves in three samples from the autumn harvesting. Three samples also each contained shells and plastic components from packaging and bottles.

Before the samples were subjected to further analyses, these materials were removed from the samples and the sediment was washed.

No similar investigations to determine the sediment contents of harvested aquatic plant material can be found in the literature up to now. In order to classify the results presented in Tables 1 and 2, the sediment contents in five substrates from operational agricultural biogas plants-two maize silages and three grass silages-were investigated. All these substrates had a sediment content of greater than $1 \%$ TS (see Table 3). In one case, grass silage even had a sediment content of $6.4 \%$ TS, i.e., higher than $95 \%$ of the aquatic plant samples.

Table 3. Sediment contents in silages from operational biogas plants.

\begin{tabular}{cc}
\hline Silage & Sediment Content (\%TS) \\
\hline Maize \#1 & 2.20 \\
Maize \#2 & 1.30 \\
Grass \#1 & 1.10 \\
Grass \#2 & 2.00 \\
Grass \#3 & 6.40 \\
\hline
\end{tabular}

To summarize, it was observed that the sediment content in 37 of 39 samples of aquatic plant material was less than $4 \%$ and thus does not represent a hindrance to use as a substrate in biogas plants. However, scientists have reported that unexpected objects, such as plastic bottles, drinks cans, bicycles, car tires and shopping trolleys are often encountered during actual harvesting of aquatic plants from bodies of water (Liegl (Liegl GmbH \& Co. KG, Laupheim, Germany) and Podraza (Ruhrverband, Essen, Germany), personal communication). These objects must be removed by hand before the harvested material is put to any subsequent use.

\subsection{Properties of the Harvested Material}

The TS content of the biomass from aquatic plants after it was washed to remove attached sediment was $10.9 \pm 6.37 \% \mathrm{FM}$ on average (Tables 1 and 2); the average TS contents of $10.3 \pm 4.5 \% \mathrm{FM}$ in summer were lower than the values of $12.2 \pm 9.1 \%$ FM in autumn. Helophytes in the single-plant samples had a higher average TS content than hydrophytes $(12.2 \pm 6.2 \% \mathrm{FM}$ vs. $10.3 \pm 5.5 \% \mathrm{FM}$, respectively). The high TS content of watermilfoil in sample no. 8 of $19.2 \% \mathrm{FM}$ can be ascribed to the high sediment content. Separation of the sediment from the plant matter was probably not completely successful in this case. The rather low VS content of this sample of $47.2 \%$ also supports this explanation.

The VS content of the aquatic plant biomass (APB) was $79.8 \pm 10.6 \%$ TS on average. As is the case with TS content, plant-specific differences can also be identified here. Submerged and emergent plants had lower average VS contents of $74.1 \pm 12.0 \%$ TS than helophytes at $84.0 \pm 6.7 \%$ TS.

The average $\mathrm{C} / \mathrm{N}$ ratio was $17.9 \pm 6.9$ for all aquatic plants (Tables 4 and 5). No sample had a $\mathrm{C} / \mathrm{N}$ ratio less than 10 or higher than 40 . The highest values were measured in samples from autumn harvesting where reed was the main component (34.6, 34.1 and 31.1 in samples 16, 35 and 30, respectively). Kobayashi et al. [18] investigated the characteristics of eight submersed aquatic macrophytes from lakes in Japan (Hydrilla verticillata L. F. ROYLE, Potamogeton $x$ inbaensis Kadono, P. dentatus Hagstr., P. malaianus Miquel, Ceratophyllum demersum L., P. perfoliatus L., Myriophyllum aquaticum (VELL.) VERDC. and E. densa PLANCH). The $\mathrm{C} / \mathrm{N}$ ratio varied between 8.5 and 12.9, with an average of 10.3 [18]. However, the optimal C/N ratio of substrates for anaerobic 
fermentation ranges between 15 and 30 [19]. This applies for $49 \%$ of aquatic plant samples investigated in Germany (Tables 4 and 5). 74\% of all samples had a $\mathrm{C} / \mathrm{N}$ ratio in the range 10-20. Co-fermentation with carbon-rich substrates would be beneficial for these samples.

Table 4. Carbon and nitrogen contents in plant material in samples from standing bodies of water (Samples 8-10 are from summer harvesting).

\begin{tabular}{cccc}
\hline Sample No. & Nitrogen $(\mathbf{g} / \mathbf{k g}$ TS) & Carbon $(\mathbf{g} / \mathbf{k g}$ TS) & $\mathbf{C} / \mathbf{N}$ \\
\hline 1 & 30.1 & 354 & 11.8 \\
2 & 24.8 & 360 & 14.5 \\
3 & 24.3 & 385 & 15.8 \\
4 & 19.9 & 367 & 18.4 \\
5 & 18.2 & 398 & 21.9 \\
6 & 16.0 & 397 & 24.8 \\
7 & 24.3 & 385 & 15.8 \\
8 & 6.03 & 172 & 28.6 \\
9 & 36.0 & 396 & 11.0 \\
10 & 17.3 & 371 & 21.4 \\
11 & 16.0 & 325 & 20.3 \\
12 & 20.1 & 283 & 14.1 \\
13 & 19.9 & 363 & 18.3 \\
\hline
\end{tabular}

Table 5. Carbon and nitrogen contents in plant material in samples from flowing bodies of water (samples 33-39 are from summer harvesting).

\begin{tabular}{cccc}
\hline Sample No. & Nitrogen $(\mathbf{g} / \mathbf{k g}$ TS) & Carbon $\mathbf{( g / k g ~ T S )}$ & $\mathbf{C} / \mathbf{N}$ \\
\hline 14 & 26.6 & 397 & 14.9 \\
15 & 26.2 & 393 & 15.0 \\
16 & 12.2 & 422 & 34.6 \\
17 & 14.2 & 419 & 29.5 \\
18 & 27.3 & 361 & 13.2 \\
19 & 24.1 & 397 & 16.5 \\
20 & 29.3 & 424 & 14.5 \\
21 & 12.8 & 436 & 34.1 \\
22 & 28.8 & 394 & 13.7 \\
23 & 25.9 & 389 & 15.0 \\
24 & 25.1 & 350 & 14.0 \\
25 & 23.5 & 356 & 15.1 \\
26 & 32.8 & 354 & 10.8 \\
27 & 24.2 & 430 & 17.7 \\
28 & 26.7 & 422 & 15.8 \\
29 & 30.4 & 456 & 13.7 \\
30 & 14.0 & 435 & 31.1 \\
31 & 33.9 & 383 & 11.3 \\
32 & 26.2 & 345 & 13.2 \\
33 & 16.2 & 292 & 18.1 \\
34 & 34.9 & 349 & 10.0 \\
35 & 11.7 & 400 & 34.1 \\
36 & 25.9 & 314 & 12.1 \\
37 & 28.4 & 368 & 13.0 \\
38 & 27.7 & 403 & 14.6 \\
39 & 27.2 & 389 & 14.3 \\
\hline & & &
\end{tabular}

In the context of the use of aquatic plants as fertilizers or as substrates in biogas plants, it is advantageous to know the concentrations of the most important macroelements and heavy metals. The results of the analyses are summarized in Tables 6 and 7. The concentrations of nitrogen $(23.3 \pm 7.1 \mathrm{~g} / \mathrm{kg}$ TS $)$ and phosphorus $(2.73 \pm 1.41 \mathrm{~g} / \mathrm{kg}$ TS $)$ were comparable with literature values for grass silages with an N content of $23.5 \pm 4.25 \mathrm{~g} / \mathrm{kg}$ TS and a P content of $2.8 \pm 0.50 \mathrm{~g} / \mathrm{kg}$ TS [20]. 
In contrast, the potassium concentrations of $12.8 \pm 8.9 \mathrm{~g} / \mathrm{kg}$ TS on average were significantly less than the potassium concentrations of grass silages $(23.5 \pm 6.01 \mathrm{~g} / \mathrm{kg}$ TS [20]). With regard to heavy metals, 36 of 39 samples were under the German legal limit values for biogenic waste [21]. The threshold concentration of nickel was exceeded in the case of sample no. 2; the zinc legal limit was exceeded very slightly in the case of sample no. 1 . Sample no. 31 showed higher values of two elements-cadmium and zinc. As stated in the literature [16,22,23], the heavy metal contents in the aquatic biomass depend on their concentration in water and sediment, and vary considerably on a regional basis.

Table 6. Concentrations of elements in plant material in samples from standing bodies of water.

\begin{tabular}{|c|c|c|c|c|c|}
\hline Element & $\begin{array}{l}\text { Mean Value } \\
\text { (mg/kg TS) }\end{array}$ & $\begin{array}{c}\text { Standard } \\
\text { Deviation }\end{array}$ & $\begin{array}{l}\text { Minimum } \\
\text { (mg/kg TS) }\end{array}$ & $\begin{array}{l}\text { Maximum } \\
\text { (mg/kg TS) }\end{array}$ & $\begin{array}{c}\text { Legal Limit }{ }^{1} \\
(\mathrm{mg} / \mathrm{kg} \text { TS) }\end{array}$ \\
\hline $\mathrm{Al}$ & 827 & 1151 & 13.0 & 3320 & \\
\hline As & 1.47 & 1.32 & 0.17 & 4.35 & \\
\hline B & 19.4 & 10.4 & 6.11 & 42.0 & \\
\hline $\mathrm{Ca}$ & 38,860 & 31,906 & 8630 & 119,650 & \\
\hline $\mathrm{Cd}$ & 0.17 & 0.21 & 0.02 & 0.47 & 1 \\
\hline Co & 4.44 & 9.71 & 0.07 & 33.0 & \\
\hline $\mathrm{Cr}$ & 1.84 & 2.01 & 0.27 & 6.44 & 70 \\
\hline $\mathrm{Cu}$ & 16.7 & 21.5 & 1.6 & 62.0 & 70 \\
\hline $\mathrm{Fe}$ & 2181 & 2785 & 61 & 7880 & \\
\hline K & 12,662 & 11,780 & 2310 & 46,330 & \\
\hline $\mathrm{Mg}$ & 2967 & 1094 & 842 & 4210 & \\
\hline $\mathrm{Mn}$ & 868 & 1026 & 28.8 & 2810 & \\
\hline Mo & 0.34 & 0.30 & 0.08 & 0.68 & \\
\hline $\mathrm{Ni}$ & 6.46 & 12.1 & 0.43 & 42.0 & 35 \\
\hline $\mathrm{P}$ & 1847 & 908 & 474 & 3190 & \\
\hline $\mathrm{Pb}$ & 2.40 & 2.81 & 0.11 & 7.80 & 100 \\
\hline$S$ & 3065 & 1441 & 1270 & 6570 & \\
\hline $\mathrm{Zn}$ & 57.5 & 90.7 & 8.92 & 305 & 300 \\
\hline
\end{tabular}

${ }^{1}$ according to German regulation on the reclamation of bio waste of agricultural, sivicultural or horticultural soils "BioAbfV" [21].

Table 7. Concentrations of elements in plant material in samples from flowing bodies of water.

\begin{tabular}{|c|c|c|c|c|c|}
\hline Element & $\begin{array}{c}\text { Mean Value } \\
(\mathrm{mg} / \mathrm{kg} \text { TS) }\end{array}$ & $\begin{array}{c}\text { Standard } \\
\text { Deviation }\end{array}$ & $\begin{array}{l}\text { Minimum } \\
\text { (mg/kg TS) }\end{array}$ & $\begin{array}{l}\text { Maximum } \\
(\mathrm{mg} / \mathrm{kg} \text { TS) }\end{array}$ & $\begin{array}{c}\text { Legal Limit }{ }^{1} \\
(\mathrm{mg} / \mathrm{kg} \text { TS) }\end{array}$ \\
\hline $\mathrm{Al}$ & 844 & 710 & 57.5 & 2690 & \\
\hline As & 3.11 & 4.40 & 0.10 & 22.0 & \\
\hline $\mathrm{B}$ & 121 & 209 & 5.01 & 891 & \\
\hline $\mathrm{Ca}$ & 24,778 & 32,865 & 4220 & 175,500 & \\
\hline $\mathrm{Cd}$ & 0.36 & 0.41 & 0.06 & 1.40 & 1 \\
\hline $\mathrm{Co}$ & 4.45 & 6.89 & 0.09 & 27.0 & \\
\hline $\mathrm{Cr}$ & 2.23 & 1.82 & 0.19 & 6.60 & 70 \\
\hline $\mathrm{Cu}$ & 17.9 & 14.2 & 1.90 & 54.0 & 70 \\
\hline $\mathrm{Fe}$ & 6021 & 6125 & 360 & 24,130 & \\
\hline $\mathrm{K}$ & 12,247 & 7180 & 1960 & 32,600 & \\
\hline $\mathrm{Mg}$ & 1935 & 696 & 662 & 3220 & \\
\hline $\mathrm{Mn}$ & 5320 & 6237 & 110 & 26,020 & \\
\hline Mo & 1.01 & 0.86 & 0.14 & 3.80 & \\
\hline $\mathrm{Ni}$ & 3.72 & 3.78 & 0.51 & 15.0 & 35 \\
\hline $\mathrm{P}$ & 3209 & 1529 & 932 & 8320 & \\
\hline $\mathrm{Pb}$ & 4.80 & 5.04 & 0.37 & 17.0 & 100 \\
\hline$S$ & 3535 & 1593 & 1520 & 6760 & \\
\hline $\mathrm{Zn}$ & 103 & 162 & 15.0 & 815 & 300 \\
\hline
\end{tabular}

${ }^{1}$ according to German regulation on the reclamation of bio waste of agricultural, sivicultural or horticultural soils "BioAbfV" [21]. 
The concentrations of trace elements, such as molybdenum, iron, zinc, nickel and cobalt [24], that are important for anaerobic digestion are shown in Tables 6 and 7. Compared to the trace elements concentrations in maize silage published by Pobeheim et al. [25], lower molybdenum (maize silage (MS): $0.8 \mathrm{~g} / \mathrm{kg}$ TS versus APB: $0.34 \pm 0.30 \mathrm{mg} / \mathrm{kg}$ TS), but higher iron (MS: $80 \mathrm{mg} / \mathrm{kg}$ TS versus APB: $2181 \pm 2781 \mathrm{mg} / \mathrm{kg}$ TS), cobalt (MS: $<0.05 \mathrm{mg} / \mathrm{kg}$ TS versus APB: $4.44 \pm 9.71 \mathrm{mg} / \mathrm{kg}$ TS), and nickel (MS: $0.7 \mathrm{mg} / \mathrm{kg}$ TS versus APB: $6.46 \pm 12.1 \mathrm{mg} / \mathrm{kg}$ TS) concentrations are present in APB.

\subsection{Methane Potential of Aquatic Plants}

Determination of the methane yield of aquatic plants is essential in order to evaluate their potential use in biogas plants. The experiments carried out showed that the plants have good digestibility (see Table 8 ). The highest biogas and methane yields were achieved by floating sweet grass $\left(372 \pm 19 \mathrm{~L}_{\mathrm{CH} 4} / \mathrm{kg} \mathrm{VS}\right)$. Reed had the lowest specific methane yield (142 $\left.\pm 4.5 \mathrm{~L}_{\mathrm{CH} 4} / \mathrm{kg} \mathrm{VS}\right)$, even though its methane yield per unit fresh mass was the highest at $50.6 \pm 4.4 \mathrm{~L}_{\mathrm{CH} 4} / \mathrm{kg}$ VS. In addition, reed also had the lowest methane concentration at the end of the experiment at $53 \%$. The poor biogas production when reed is used is mainly due to the high degree of lignification of the blades of reed, as already described by Lizasoain et al. [13]. If the overall analysis results for all aquatic plants from the two harvesting campaigns in Germany are considered, non-pretreated reed can be identified as the least suitable substrate for anaerobic fermentation.

Table 8. Methane yields of selected aquatic plants.

\begin{tabular}{|c|c|c|c|c|}
\hline $\begin{array}{l}\text { Origin/Sample } \\
\text { No. }\end{array}$ & Aquatic Plant Species & Test System & $\begin{array}{l}\text { Methane Yield } \\
\text { (L/kg FM) }\end{array}$ & $\begin{array}{c}\text { Specific Methane } \\
\text { Yield (SMY) (L/kg VS) }\end{array}$ \\
\hline 3 & $\begin{array}{l}\text { Water horsetail } \\
\text { (Equisetum fluviatile) }\end{array}$ & AMPTS & $20.2 \pm 1.1$ & $190 \pm 10$ \\
\hline 7 & $\begin{array}{l}\text { Yellow water-lily } \\
\text { (Nuphar lutea) }\end{array}$ & FBTS & $19.9 \pm 2.7$ & $202 \pm 22$ \\
\hline 12 & $\begin{array}{l}\text { Western waterweed } \\
\text { (Elodea nuttallii) }\end{array}$ & AMPTS & $13.9 \pm 0.4$ & $204 \pm 6.0$ \\
\hline 20 & $\begin{array}{l}\text { Floating sweet-grass } \\
\text { (Glyceria fluitans) }\end{array}$ & AMPTS & $18.1 \pm 0.9$ & $372 \pm 19$ \\
\hline 21 & $\begin{array}{l}\text { Reed } \\
\text { (Phragmites australis) }\end{array}$ & AMPTS & $22.2 \pm 1.5$ & $169 \pm 12$ \\
\hline \multirow[t]{2}{*}{37} & $\begin{array}{l}\text { Bur-reed } \\
\text { (Sparganium sp.) }\end{array}$ & AMPTS & $16.6 \pm 0.2$ & $223 \pm 2.6$ \\
\hline & Fresh material & & & \\
\hline Parthe & $\begin{array}{l}\text { Western waterweed } \\
\text { (Elodea nuttallii) }\end{array}$ & FBTS & $12.3 \pm 0.5$ & $233 \pm 11$ \\
\hline $\begin{array}{l}\text { Karl Heine } \\
\text { Canal }\end{array}$ & $\begin{array}{l}\text { Watermilfoil } \\
\text { (Myriophyllum } \\
\text { heterophyllum) }\end{array}$ & FBTS & $8.8 \pm 2.2$ & $160 \pm 26$ \\
\hline Parthe & $\begin{array}{l}\text { River water-crowfoot } \\
\text { (Ranunculus fluitans) }\end{array}$ & FBTS & $15.7 \pm 2.4$ & $222 \pm 6.0$ \\
\hline Parthe & $\begin{array}{l}\text { Water-starwort } \\
\text { (Callitriche sp.) }\end{array}$ & FBTS & $12.0 \pm 0.5$ & $292 \pm 34$ \\
\hline
\end{tabular}

AMPTS—automatic methane potential test system, FBTS—fermentation batch test system.

The calculated specific methane yields (Table 8) are quite low compared to energy crops, but do achieve gas yields similar to those of farm-produced fertilizers, such as cattle slurry, in certain cases at values of $242.7 \pm 60.2 \mathrm{~L}_{\mathrm{CH} 4} / \mathrm{kg}$ VS [26] or of non-pretreated hay at values of $243 \mathrm{~L}_{\mathrm{CH} 4} / \mathrm{kg}$ VS [27]. Relatively low biogas yields are less critical for aquatic plants, as they are a residual material that 
results from harvesting that would have to be carried out anyway and this material would also have to be disposed of in any case. In addition, aquatic plants contain trace elements that could be significant in the stabilization of the anaerobic biogas process [8].

Labatut et al. [26] determined the methane yields of many different complex substrates, including the four aquatic neophytes of Eurasian milfoil (Myriophyllum spicatum L.), frogbit (Hydrocharis morsus-ranae L.), water chestnut (Eleocharis dulcis (BURM. F.) TRIN. EX HENSCH.) and water celery (Apium inundatum (L.) W.D.J.KOCH) from Oneida lake and Oneida river. The methane yields ranged between 279 and $451 \mathrm{~L}_{\mathrm{CH} 4} / \mathrm{kg}$ VS, with $M$. spicatum responsible for the lowest value. These methane yields are significantly higher than those achieved in the batch test described here $\left(160 \pm 26 \mathrm{~L}_{\mathrm{CH}} / \mathrm{kg}_{\mathrm{g}}\right.$ VS in Table 8). However, the value provided by Labatut et al. [26] is the average of two values with a very high standard deviation of around $148 \mathrm{~L}_{\mathrm{CH} 4} / \mathrm{kg}$ VS (measured from the graphic in Figure 1 of the article).

Most studies confine themselves to anaerobic fermentation of submersed aquatic plants. Samples of E. nuttallii from five different locations in Germany were investigated in Zehnsdorf et al. [8]. The reported methane yields ranged from 261.8 to $301.6 \mathrm{~L}_{\mathrm{CH} 4} / \mathrm{kg}$ VS. This is slightly higher than the values of 206 and $233 \mathrm{~L}_{\mathrm{CH} 4} / \mathrm{kg}$ VS presented in Table 8 . The eight submersed aquatic plants investigated by Kobayashi et al. [18] produced methane yields of 275 (E. crappipes) to $418 \mathrm{~L}_{\mathrm{CH} 4} / \mathrm{kg}$ VS (M. aquaticum). In the case of five submersed macrophytes from Lake Biwa in Japan analysed by Koyama et al. [28] (Ceratophyllum demersum L., E. densa, E. nuttallii, Potamogeton maackianus A. BEN and Potamogeton malaianus MIQUEL), the methane yields ranged from 161.2 to $360.8 \mathrm{~L} / \mathrm{kg}$ VS depending on the species being investigated. The highest methane yield was achieved for the fermentation of $E$. nuttalii and was higher than the methane yields presented in Table 8. The lowest methane yield was achieved in the case of fermentation of P. maackianus. The reason given for this low digestibility was the high degree of lignification of the tissue, as the lignin content of this plant was up to $20.7 \%$ TS. In comparison, E. nuttallii contained just 3.2\% lignin in its dry matter [28].

Aquatic helophytes, such as reed, also have a high degree of lignification. Lizasoain et al. [13] reported a methane yield of $188 \mathrm{~L}_{\mathrm{CH} 4} / \mathrm{kg}$ VS for non-pretreated reed, which is slightly higher than the methane yield of $169 \pm 12 \mathrm{~L}_{\mathrm{CH} 4} / \mathrm{kg}$ VS presented in Table 8. By employing suitable pre-treatment with the aid of steam explosion $\left(220^{\circ} \mathrm{C}, 15 \mathrm{~min}\right)$, the authors achieved a specific methane yield that was up to $89 \%$ higher than that of untreated reed [13]. Further experiments on lignin pulping were carried out by Koyama et al. [29] using the aquatic plant $P$. malaianus. The methane yield was increased by $66 \%$ from $161 \mathrm{~L}_{\mathrm{CH} 4} / \mathrm{kg}$ VS for untreated material to $243 \mathrm{~L}_{\mathrm{CH} 4} / \mathrm{kg}$ VS after alkaline thermochemical pre-treatment. However, the same authors showed in a different article [30] that the products of this type of pre-treatment have a negative influence on the microbial hydrolysis stage of the biogas process. In addition, it must be considered whether the benefits for anaerobic fermentation justify the increased costs for pre-treatment. It would be a better idea to adapt the use of aquatic macrophytes to suit their properties: Aquatic plants with low lignin contents can be used for biogas production, while plants with a high lignin content are more suitable as a structural material for composting.

\section{Conclusions}

To conclude, the sediment content of aquatic plant material from two harvesting campaigns from waters in Germany was not greater than in conventional silages. Analyses of macroelements nitrogen and phosphorus showed results similar to those of grass silages. The methane yields between 142 and $372 \mathrm{~L}_{\mathrm{CH} 4} / \mathrm{kg}$ VS were comparable to those of farm-produced agricultural residues. These results show the great diversity in the quality of the aquatic biomass, which depends more on the prevailing plant species than on the harvest time or the location and the type of water body. In general, it was shown that the aquatic plants are well suited as a substrate in biogas plants.

This is the first study to investigate the suitability of aquatic plant material for anaerobic fermentation in Germany. For the future, integrating the harvested biomass into the substrate mix 
in a biogas plant could be a major challenge. For this reason, further investigations into the political framework conditions and national legislature are of great importance.

Author Contributions: Conceptualization, A.Z. and W.S.; methodology, L.M. and H.W.; investigation, A.B., H.W. and L.M.; writing—original draft preparation, L.M. and A.B.; writing—review and editing A.Z., A.B., W.S. and H.W.; supervision, A.Z.; project administration, A.Z.; funding acquisition, A.Z. and W.S.

Funding: This research was funded by the Federal Ministry of Food and Agriculture based on a decision of the German Bundestag with funds from the "Energy and Climate Fund" investment fund, grant number 22403013.

Acknowledgments: The authors would like to thank the water maintenance personnel who provided them with samples of aquatic plants taken during mowing campaigns. The authors would like to thank Harald Auge for analysis of macroelements, carbon and nitrogen; Steffen Schmidt for the determination of the sediment content; and also Hans-Joachim Stärk for analysis of the elements by ICP-OES and ICP-MS.

Conflicts of Interest: The authors declare no conflict of interest. The funders had no role in the design of the study; in the collection, analyses, or interpretation of data; in the writing of the manuscript, or in the decision to publish the results.

\section{References}

1. Guilizzoni, P. The role of heavy metals and toxic materials in the physiological ecology of submersed macrophytes. Aquat. Bot. 1991, 41, 87-109. [CrossRef]

2. Boyd, C.E. Vascular Aquatic Plants for Mineral Nutrient Removal from Polluted Waters. Econ. Bot. 1970, 24, 95-103. [CrossRef]

3. Stabenau, N.; Zehnsdorf, A.; Rönicke, H.; Wedwitschka, H.; Moeller, L.; Ibrahim, B.; Stinner, W. A potential phosphorous fertilizer for organic farming: Recovery of phosphorous resources in the course of bioenergy production through anaerobic digestion of aquatic macrophytes. Energy Sustain. Soc. 2018, 8, 1-10. [CrossRef]

4. Verhofstad, M.J.J.M.; Poelen, M.D.M.; van Kempen, M.M.L.; Bakker, E.S.; Smolders, A.J.P. Finding the harvesting frequency to maximize nutrient removal in a constructed wetland dominated by submerged aquatic plants. Ecol. Eng. 2017, 106, 423-430. [CrossRef]

5. Meier, E.J.; Waliczek, T.M.; Abbott, M.L. Composting Invasive Plants in the Rio Grande River. Invasive Plant Sci. Manag. 2014, 7, 473-482. [CrossRef]

6. Gollasch, S.; Nehring, S. National checklist for aquatic alien species in Germany. Aquat. Invasions 2006, 1, 245-269. [CrossRef]

7. Muñoz Escobar, M.; Voyevoda, M.; Fühner, C.; Zehnsdorf, A. Potential uses of Elodea nuttallii-harvested biomass. Energy Sustain. Soc. 2011, 1. [CrossRef]

8. Zehnsdorf, A.; Korn, U.; Pröter, J.; Naumann, D.; Seirig, M.; Rönicke, H.; Pieper, B. Western waterweed (Elodea nuttallii) as a co-substrate for biogas plants. Agric. Eng. 2011, 66, 136-139. [CrossRef]

9. Hussner, A.; Nehring, S.; Hilt, S. From first reports to successful control: A plea for improved management of alien aquatic plant species in Germany. Hydrobiologia 2014, 737, 321-331. [CrossRef]

10. Hussner, A.; Stiers, I.; Verhofstad, M.J.J.M.; Bakker, E.S.; Grutters, B.M.C.; Haury, J.; van Valkenburg, J.L.C.H.; Brundu, G.; Newman, J.; Clayton, J.S.; et al. Management and control methods of invasive alien freshwater aquatic plants: A review. Aquat. Bot. 2017, 136, 112-137. [CrossRef]

11. Zehnsdorf, A.; Hussner, A.; Eismann, F.; Rönicke, H.; Melzer, A. Management options of invasive Elodea nuttallii and Elodea canadensis. Limnologica 2015, 51, 110-117. [CrossRef]

12. Herbes, C.; Brummer, V.; Roth, S.; Röhl, M. Using aquatic plant biomass from de-weeding in biogas processes-An economically viable option? Energy Sustain. Soc. 2018, 8, 21. [CrossRef]

13. Lizasoain, J.; Rincón, M.; Theuretzbacher, F.; Enguídanos, R.; Nielsen, P.J.; Potthast, A.; Zweckmair, T.; Gronauer, A.; Bauer, A. Biogas production from reed biomass: Effect of pretreatment using different steam explosion condition. Biomass Bioenergy 2016, 95, 84-91. [CrossRef]

14. Yadav, D.; Barbora, L.; Bora, D.; Mitra, S.; Rangan, L.; Mahanta, P. An assessment of duckweed as a potential lignocellulosic feedstock for biogas production. Int. Biodeterior. Biodegrad. 2017, 119, 253-529. [CrossRef]

15. Gaur, R.Z.; Khan, A.A.; Suthar, S. Effect of thermal pre-treatment on co-digestion of duckweed (Lemna gibba) and waste activated sludge on biogas production. Chemosphere 2017, 174, 754-763. [CrossRef] [PubMed] 
16. Zehnsdorf, A.; Moeller, L.; Stärk, H.-J.; Auge, H.; Röhl, M.; Stinner, W. The study of the variability of biomass from plants of the Elodea genus from a river in Germany over a period of two hydrological years for investigating their suitability for biogas production. Energy Sustain. Soc. 2017, 7, 15. [CrossRef]

17. Moeller, L.; Zehnsdorf, A. Measures to prevent foam formation in the anaerobic digestion of sugar beet in biogas plants. Agric. Eng. 2017, 72, 13-22. [CrossRef]

18. Kobayashi, T.; Wu, Y.-P.; Lu, Z.-J.; Xu, K.-Q. Characterization of Anaerobic Degradability and Kinetics of Harvested Submerged Aquatic Weeds Used for Nutrient Phytoremediation. Energies 2015, 8, 304-318. [CrossRef]

19. Weiland, P. Biogas production: Current state and perspectives. Appl. Microbiol. Biotechnol. 2010, 85, 849-860. [CrossRef] [PubMed]

20. Salo, T.; Eurola, M.; Rinne, M.; Seppälä, A.; Kaseva, J.; Kousa, T. The Effect of Nitrogen and Phophorus Concentrations on Nutrient Balances of Cereals and Grass Silage. MTT Report No. 147. 2014. Available online: http:/ /jukuri.luke.fi/handle/10024/482918 (accessed on 19 September 2018).

21. Bioabfallverordnung BioAbfV 2017 (German Regulation on the Reclamation of Bio Waste of Agricultural, Sivicultural or Horticultural Soils), §4 REQUIREMENTS Regarding Pollutants and Other Parameters. Available online: https:/ / www.gesetze-im-internet.de/bioabfv/ (accessed on 19 September 2018).

22. Gouder de Beauregard, A.-C.; Mahy, G. Phytoremediation of heavy metals: The role of macrophytes in a stormwater basin. Ecohydrol. Hydrobiol. 2002, 2, 289-295.

23. Maleva, M.G.; Nekrasova, G.F.; Bezel, V.S. The response of hydrophytes to environmental pollution with heavy metals. Russ. J. Ecol. 2004, 35, 230-235. [CrossRef]

24. Demirel, B.; Scherer, P. Trace elements requirements of agricultural biogas digesters during biological conversion of renewable biomass to methane. Biomass Bioenergy 2011, 35, 992-998. [CrossRef]

25. Pobeheim, H.; Munk, B.; Johansson, J.; Guebitz, G.M. Influence of trace elements on methane formation from a synthetic model substrate for maize silage. Bioresour. Technol. 2010, 101, 836-839. [CrossRef] [PubMed]

26. Labatut, R.A.; Angenent, L.T.; Scott, N.R. Biochemical methane potential and biodegradability of complex organic substrates. Bioresour. Technol. 2011, 201, 2255-2264. [CrossRef] [PubMed]

27. Bauer, A.; Lizasoain, J.; Theuretzbach, F.; Agger, J.W.; Rincón, M.; Menardo, S.; Saylor, M.K.; Enguídanos, R.; Nielsen, P.J.; Potthast, A.; et al. Steam explosion pretreatment for enhancing biogas production of late harvested hay. Bioresour. Technol. 2014, 166, 403-410. [CrossRef] [PubMed]

28. Koyama, M.; Yamamoto, S.; Ishikawa, K.; Ban, S.; Toda, T. Anaerobic digestion of submerged macrophytes: Chemical composition and anaerobic digestibility. Ecol. Eng. 2014, 69, 304-309. [CrossRef]

29. Koyama, M.; Yamamoto, S.; Ishikawa, K.; Ban, S.; Toda, T. Enhancing anaerobic digestibility of lignin-rich submerged macrophyte using thermochemical pre-treatment. Biochem. Eng. J. 2015, 99, 124-130. [CrossRef]

30. Koyama, M.; Yamamoto, S.; Ishikawa, K.; Ban, S.; Toda, S. Inhibition of anaerobic digestion by dissolved lignin derived from alkaline pre-treatment of an aquatic macrophyte. Chem. Eng. J. 2017, 311, 55-62. [CrossRef]

(C) 2018 by the authors. Licensee MDPI, Basel, Switzerland. This article is an open access article distributed under the terms and conditions of the Creative Commons Attribution (CC BY) license (http:// creativecommons.org/licenses/by/4.0/). 